\title{
The Role of the Islamic Banks in Increasing Domestic Saving and Funding Economic Development in Jordan
}

\author{
SALAH TURKI ATEIWI ALRAWAHDEH, \\ Department of economics / Faculty of business, Al Balqa Applied University, \\ JORDAN \\ ALI ABDEL FATTAH HAMDA ZYADAT, \\ Department of economics, Faculty of business / Al Balqa Applied University, \\ JORDAN
}

\begin{abstract}
This article explored the role of Islamic banks in increasing the amount of domestic savings and funding the economic development process in Jordan during the period (2010-2019). A descriptive analytical approach was adopted. The data was obtained from the Association of Banks in Jordan. It was analyzed through carrying out the linear regression analysis. The researchers concluded that the assets of Jordanian Islamic banks increased. That indicates that there was an increase in the savings of Islamic banks. They found that the total credit facilities provided by Islamic banks to individuals and for all sectors have increased. They found that there is a positive significant relationship between the assets in Islamic banks from one hand and credit facilities from another hand. They recommend exerting effort to increase the savings of Islamic banks.
\end{abstract}

Keywords: Islamic Banks, Domestic Saving, Economic Development

Received: December 1, 2021. Revised: May 7, 2021. Accepted: May 15, 2021. Published: May 21, 2021.

\section{Introduction}

Financial institutions contribute to fostering the development of economy. Banks are significant financial institutions. They significantly influence the national economy. They include Islamic banks, which constitute a great percentage of banks in Islamic and Arab countries, including Jordan. There is a great demand on Islamic funding formulas, by companies and individuals. Such formulas significantly affect the economic growth level. The latter formulas comply with the provisions of Shariah. The demand on Islamic funding formulas by the owners of projects has been increasing during the past three decades. In fact, more than 75 countries have Islamic banking institutions. Today, there are more than 292 banks which are fully Islamic or have branches for carrying out Islamic transactions [6]

The Islamic funding methods are based on feasibility studies. They show compliance with the provisions of Shariah. These methods do not transfer between financing institutions and taking 
adequate guarantees that secure their funds. It also transfers the financing from the method of guarantee and fixed return to the method of risk and participation, and the gain with the fine, and the productive activity prevailing over the financial activity, and consolidates the concept of control and follow-up on the financing granted, and takes into account the conditions of defaulters [2]

The first attempt for showing compliance with the provisions of Shariah in banking institutions was carried out forty years ago. It is represented in creating saving banks in Egypt in 1963. Similar attempts were carried out in Pakistan. Regarding Dubai Islamic Bank, it was designed in 1975. It is the $1^{\text {st }}$ Islamic bank which provides Islamic banking services. It carries out investment activities and provides investment services. After that, several Islamic banks were established. They include: Faisal Islamic Bank in Egypt, Kuwait Finance House in Kuwait, and Faisal Islamic Bank in Sudan. After that, Jordan Islamic Bank for Finance and Investment was created in 1988. Luxembourg International Bank for Investment and Development was established in Egypt in 1980. In 1980, there were 25 Islamic banks. In 1985, there were 52 Islamic banks [13]

Obada and Melhem [11] suggest that Islamic banks and other funding institutions provide Islamic funding service through concluding contracts. The Islamic funding formulas include: Murabahah, and lease-purchase contract. They are provided in accordance with the relevant laws and legislations. They are offered to various people and institutions. Thus, they affect various economic sectors in society.

Islamic banks were established for avoiding the process of carrying out funding contracts with commercial banks. They aim at fostering the process of achieving economic development. The focus of Islamic banks is represented in short-term loans for obtaining profit quickly [5]

The demand on Islamic financial products and services has been significantly increasing. Such an increase is attributed to the performance efficiency of Islamic financial institutions. It is also attributed to the fact that the latter institutions respond fast to crises. It's attributed to the fact that those institutions contribute to fostering social development. The latter development serves as the basis for achieving development in economic areas in all countries, including developing and developed ones. Islamic funding products and services comply with the provisions of Shariah and the economic laws and legislations [8]

There are numerous funding products and services offered by Islamic banks and financial institutions. Such services are the two main types: funding services which are based on obtaining a percentage in the return on investment and funding services that are based on indebtedness [4] The Islamic bank encourage customers to raise their savings. They mobilize savings that are supposed to be re-invested in various investment activities. It should be note that the volume of voluntary reserves withheld from Islamic banks operating in Jordan has been increasing [11]

Islamic banks play a very significant role in fostering the process of achieving economic development. That is attributed to having millions of dollars in the saving accounts of those banks. It is attributed to the fact that the latter banks offer many finding projects and services for individuals and companies. It is attributed to the fact that the latter bank offer many credit facilities to individuals and companies in many sectors.

\section{Statement of the Problem}

Islamic finance has been receiving a great attention by individuals and companies. It has become popular in Islamic countries including Jordan. Many sectors and individuals save their funds in Islamic banks. In this regard, this article explored the role of Islamic banks in increasing the amount of domestic savings and funding the economic development process in Jordan during the period (2010-2019). 


\section{Objectives and Questions}

The present study explored the role of Islamic banks in increasing the amount of domestic savings and funding the economic development process in Jordan during the period (2010-2019). It answers those questions

Q.1: What is role of Islamic banks in increase domestic saving in Jordan?

Q.2: What is the relationship between the volume of Islamic banks assets and the extent of funding economic development in Jordan?

\section{The Study's Significance}

This article is significant because it explored the degree to which Islamic banks contribute in achieving development in economic areas, through the optimal use of their savings. It is necessary to shed a light on that due to the rise of demand on the services of Islamic financial and banking institutions.

\section{The Definition of Terms}

Islamic banks: They are banking institutions that offer Islamic funding formulas.

Domestic saving: It is the value of savings from money deposited in Islamic banks, and it has been measured in this study through the value of assets of Islamic banks.

Economic development: It refers to having a rise in the average per capita share of the gross national product during a specific period of time. It is achieved through raising the average productivity of individual. It is achieved through using the available resources for raising the production level during that period.

\section{The Study's Limits}

This article targets Islamic banks in Jordan. It targets the period (2010-2019).

\section{Literature Review}

This article reviewed several studies which are listed below:

Hassan [6] explored the role of Islamic funding formulas in providing support to small enterprises. He explored the role of such formulas in raising the number of small enterprises. He investigated the role of Islamic funding formulas in fostering the development of such enterprises. He addressed the meaning of the expressions: (Islamic finance) and (small enterprises). He addressed the obstacles that hinder the owners of enterprises from achieving development. He explored the benefits of Islamic funding formulas. He found that there are several obstacles that hinder the owners of small enterprises from receiving funding services by banks. Such obstacles include administrative obstacles. He concluded that such banks play a major role due to the Islamic funding formula they offer. He found that such banks adopt certain strategies for providing such enterprises with the employees having the necessary expertise.

Obada and Melhem [11] addressed the significance of the economic role of Islamic banking funding in Jordan. They addressed that through measuring the impact of such funding on savings and investment, unemployment, inflation and GDP rates during the period (2001 - 2016). They carried out a regression analysis. They found that there the Islamic funding provided by Arab Islamic Bank doesn't have any impact on inflation, GDP and unemployment. They found that the Islamic funding provided by Jordan Islamic Bank has a significant impact on inflation. They found that the funding provided by Jordanian Islamic Bank doesn't have any significant impact on unemployment and the GDP rates. They also found that the greatest percentage of Islamic banking funding is dedicated for the construction and housing sector followed by the business sectors.

Sharrett \& Zaghlami [8] addressed the significance of the Islamic banking funding and its revolution. They addressed the role of such funding in fostering the development of various sectors achieving development in Malaysia. In addition, 
they found that the Islamic funding mechanism and investment tools of Islamic banks are important. They found that Islamic banking funding has a major impact on GDP in Malaysia. They found that Islamic banking funding can significantly predict the GDP in Malaysia.

Al-Fawwaz et al. [9] investigated the impact of Islamic funding that is provided by the Jordanian Islamic Bank on several macroeconomic variables during the period (2001 - 2011). They carried out the regression analysis to test the study's hypotheses. They found that Islamic banking finance positively affects the outcomes. A negative significant relationship exists between the rate of inflation and Islamic finance. Islamic finance improves the production level which contributes to reducing prices. They recommend paying more attention to Islamic finance.

Abu Shanab [3] explored the role of Islamic funding models in funding SMEs and providing them with support and increasing their number in Jordan. They reviewed the literature that sheds a light on Islamic funding models. They addressed the problems and challenges faced by these institutions. They analyzed data and found that funding SMEs affect the poverty and unemployment in Jordan. Thus, funding SMEs must be provided with more attention to reduce the rates of poverty and unemployment in Jordan.

Al-Da' as and Al-Jaarat [1] addressed the role of Islamic banks in the development of SMEs. They addressed the characteristics of the Islamic finance system. They addressed the effectiveness of Islamic funding methods in offering support to SMEs. They target the Jordanian Islamic Bank, and the study concluded The insignificant financing of Islamic banks for SMEs, as well as the limitation of the financing methods in Islamic banks for SMEs to the method of murabahah to the one who ordered the purchase, and the method of participation ending with ownership within the program of financing craftsmen and professionals in the Jordanian Islamic Bank, and not relying on any other financing methods. The latter researcher found that the most prominent reason behind the choosing Islamic finance lies in belief of businessmen that the transactions carried out with Islamic banks are halal and comply with the provision of shariah. However, the need to provide certain guarantees and carry out certain procedures to prevent businessmen from being funded by those banks

Al-Assarj [2] explored the role of Islamic finance in the development of small and medium enterprises. He explored the Islamic funding formulas that are in demand the most for funding small and medium enterprises. He explored the advantages of Islamic finance. He addressed the major obstacles that hinder people from receiving Islamic funding. He found that Islamic finance formulas are very significant. He found that the latter formulas play a major role in achieving justice for the two parties who are involved in the transaction. He found that riba-based loans aim at protecting the rights of the lender at the expense of the borrower. He found that shariah include provisions that regulate investment. He explored the advantages of Islamic finance and the role of Islamic finance formulas in funding investments and supporting them and achieving justice in distribution of wealth. He explored the role of Islamic finance formulas in fighting against unemployment and poverty, and increasing the number of job opportunities.

Al-Berishi [12] explored the role of Islamic banks in achieving development in various areas, including the social and economic area. He made an assessment for the performance of Islamic banks. He explored the obstacles that hinder their growth and progress, and prevent improving the administrative works of those banks. He found that Islamic banks aim to find an alternative to riba-based banks. He found that Islamic banks play a major role fostering social and economic development and attracting customers.

Miqdad and Helles [10] explored the role Islamic banks in fostering the economic development processes in Palestine. They collected and analyzed primary and secondary data. The primary data is represented in the one obtained from Islamic banks and their branches through using a questionnaire. The questionnaire was designed by the latter researchers. The data was obtained from the managers who work at Islamic banks operating in Gaza. The latter researchers found that Islamic banks in Gaza have been showing failure in 
funding the process of achieving development. They found that Islamic banks in Gaza have been showing success in accumulating savings. They found that Islamic banks in Gaza have been showing failure in achieving economic development.

Ahmad [7] explored the role of Islamic banks in funding small enterprises. He explored the role of such banks in reducing the rate of poverty. He explored the role of such banks in generating wealth. He demonstrated the social role of Islamic banks. Bangladesh Islamic Bank Limited was targeted. The Islamic Development Bank was targets. The researcher concluded that there are several banks that provide small enterprises with Islamic funding services. Such banks can fund small enterprises with letting the owners of such enterprises incur lower costs than the costs imposed by commercial banks. Getting funding services by Islamic banks shall enable the owners of small enterprises to gain more profits.

Daly et al. [16] explored the role of Islamic banks in Egypt, Bahrain, Jordan, Kuwait, Qatar, Pakistan, Sudan, Saudi Arabia, Türkiye, and UAE in achieving development and growth. They sampled 120 banks and targeted the period 2005 and 2012. They carried out the ordinary leastsquare regression analysis. They found that such banks can increase the GPA and achieve economic development and growth.

Yousri [17] explored the role of Islamic banks in achieving economic development in Islamic countries. He collected data through reviewing books and articles. He found that such banks play an effective role in the collection of funds for investment. However, he found that such banks fail in employing those funds in the sector of production. He found that Islamic banks face internal and external challenges.

Based on the studies shown above, Islamic banks play a significant role in funding the process of achieving development in economic areas. They play a significant role in funding small and medium enterprises.

\section{Methodology}

Approach

A descriptive analytical approach was adopted. It allows researchers to meet research goals. Data was obtained from the Association of Banks in Jordan about Islamic banks during the period (2010 - 2019).

\section{Data collection}

Primary data was obtained through reviewing reports obtained from the Association of Banks in Jordan. Secondary data was obtained from books, articles and journals.

\section{Population and sample:}

The population is represented in all the Jordanian Islamic banks. As for the sample, it consists from four (4) Jordanian Islamic banks. The names of those banks are listed in table (1) below: 


\section{Table 1. Study Sample (Jordanian Islamic banks)}

\begin{tabular}{|c|l|}
\hline No & Bank \\
\hline 1 & Jordan Islamic Bank \\
\hline 2 & Islamic International Arab Bank \\
\hline 3 & Safwa Islamic Back \\
\hline 4 & Al-Rajhi Bank \\
\hline & \\
\hline
\end{tabular}

\section{Variables}

The study's variables are listed below:

The independent variables: The domestic saving in Jordan (Islamic banks assets).

The dependent variable: The funding economic development in Jordan.

\section{Statistical Analysis}

The SPSS program was used for analyzing the collected data. Several methods were used to analyze data statistically, such as: frequencies and percentages. In addition, the linear regression analysis was carried out.

\section{Results and Discussion}

\section{First Question}

Q.1: What is role of Islamic banks in increase domestic saving in Jordan?

Table 2 shows the total of assets in Jordanian Islamic banks during the period (2010-2019). This data was obtained from the records of the Association of Banks in Jordan. 
Table 2. Total assets of Jordanian Islamic banks

\begin{tabular}{|c|c|c|}
\hline Year & Assets / million JD & \% change \\
\hline 2019 & $8,857.79$ & 11.4 \\
\hline 2018 & $7,948.75$ & 3.3 \\
\hline 2017 & $7,694.09$ & 3.9 \\
\hline 2016 & $7,404.68$ & 8.4 \\
\hline 2015 & $6,831.52$ & 6.1 \\
\hline 2014 & $6,435.88$ & 12.0 \\
\hline 2013 & $5,746.51$ & 0.8 \\
\hline 2012 & $5,699.97$ & 19.6 \\
\hline 2011 & $4,765.57$ & 11.3 \\
\hline 2010 & $4,281.90$ & - \\
\hline
\end{tabular}

\section{Source: The records of the Association of Banks in Jordan}

Table (2) presents data bout that the assets of Jordanian Islamic banks. The amount of such assets in $2010(4,281.90)$ million dinars. The amount of such assets in 2019 is $(8,857.79)$ million dinars. When comparing the growth rate of the assets of Islamic banks in the years 2018 and 2019 , the growth rate represented in $11.4 \%$. Based on the latter percentage, the savings in Islamic banks increased in 2019. The latter increase may be attributed to the fact that Islamic bank in Jordan have been showing success in attracting customers.

\section{Second Question}

Q.2: What is the relationship between the volume of Islamic banks assets and the extent of funding economic development in Jordan?

Table 3 presents data about the total of assets in Jordanian Islamic banks during the period (20102019). The latter data is obtained from the records of the Association of Banks in Jordan. 
Table (3): Total credit facilities of Jordanian Islamic banks

\begin{tabular}{|c|c|c|}
\hline Year & Credit Facilities / Million JD & \% change \\
\hline 2019 & $6,318.51$ & 8.8 \\
\hline 2018 & $5,805.69$ & 9.1 \\
\hline 2017 & $5,321.91$ & 6.4 \\
\hline 2016 & $5,000.85$ & 8.5 \\
\hline 2015 & $4,609.63$ & 9.9 \\
\hline 2014 & $4,195.84$ & 9.4 \\
\hline 2013 & $3,834.68$ & 5.4 \\
\hline 2012 & $3,639.58$ & 6.9 \\
\hline 2011 & $3,405.53$ & 56.9 \\
\hline 2010 & $2,169.98$ & - \\
& & \\
\hline & & \\
\hline
\end{tabular}

Source: The records of Association of Banks in Jordan

Table (3) presents data about the total credit facilities that are provided by Islamic banks to individuals and institutions in all sectors. The 
amount of the credit facilities provided by Jordanian Islamic banks in 2019 is 6,318.51 million dinars. The amount of the credit facilities provided by Jordanian Islamic banks in 2010 is 2,169.98. Thus, when comprising the latter two amounts, the amount of the credit facilities provided by Jordanian Islamic banks increased. When comparing the amount of the credit facilities provided by Jordanian Islamic banks in 2018 and the counterpart amount in 2019, the growth rate is represented in $8.8 \%$. The latter result may be attributed to having a rise in the demand on the credit facilities provided by Jordanian Islamic banks.

To explore the relationship between the Islamic banks assets and credit facilities, a simple regression analysis was carried out. The results of the latter analysis are shown in table No. 4 and table No. 5.

Table 4. Model Summary

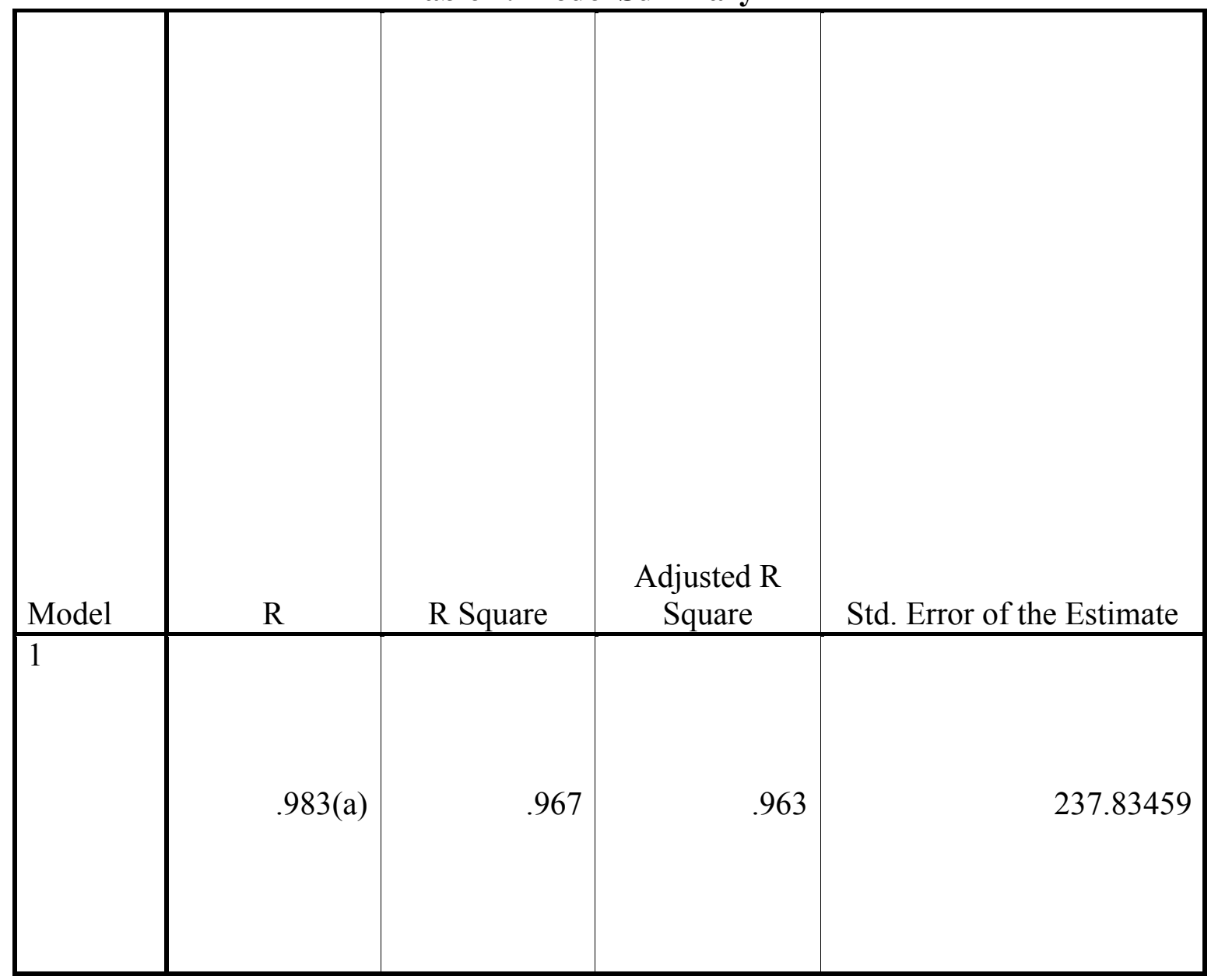

a Predictors: (Constant), Assets 
Table 5. Regression

\begin{tabular}{|c|c|c|c|c|c|c|}
\hline \multirow[b]{2}{*}{ Model } & & \multicolumn{2}{|c|}{$\begin{array}{c}\text { Unstandardized } \\
\text { Coefficients }\end{array}$} & \multirow{2}{*}{$\begin{array}{c}\text { Standardized } \\
\text { Coefficients } \\
\text { Beta }\end{array}$} & \multirow[b]{2}{*}{$t$} & \multirow[b]{2}{*}{ Sig. } \\
\hline & & B & Std. Error & & & \\
\hline 1 & (Constant) & -1058.872 & 365.114 & & -2.900 & .020 \\
\hline & Assets & .836 & .054 & .983 & 15.363 & .000 \\
\hline
\end{tabular}

a. Dependent Variable: Credit.Facilities

Based on the results presented in table No. 4 and table No. 4, there is a positive statistically significant relationship between the assets in Islamic banks and credit facilities. The correlation coefficient value is 0.983 . The determination coefficient value is 0.963 . That means that $96.3 \%$ of the changes in the credit facilities can be attributed to the assets in Jordanian Islamic banks. The researchers of the present study found that the credit facilities provided by Jordanian Islamic banks positively affect economic development.

\section{Conclusion and Recommendations}

The researchers found that Islamic banks in Jordan play a major role in increasing the GPD. They found that Islamic banks in Jordan play a major role in achieving development in economic areas. Reaching such results shall enable decision makers to make effective decisions for providing more support to Islamic banks in Jordan. Thus, the results of this study contribute to fostering the economic development of Jordan
The researchers recommend the following:

- Exerting effort to increase the savings of Islamic banks

- Facilitating the process of granting licenses to Islamic banks. That shall encourage investors to open Islamic banks. It shall contribute to increasing the number of credit facilities and fostering the process of achieving economic development.

\section{References}

[1] Al-Da'as, A., and Al-Jararat, K. The Role of Islamic Banks in Financing Small and Medium Enterprises in Jordan, Zarqa Journal for Research and Human Studies, Volume 14, No. 2. 2014

[2] Al-Assarj, H. The Role of Islamic Finance in the Development of Small and Medium Enterprises, Seminar: "Islamic Banks and their Role in Economic and Social Development", Beni Mellal University, Morocco. 2012 
[3] Abu Shanab, S. The Role of Islamic Finance in Supporting Small and Medium Enterprises (Case Study - Jordan). Baghdad College of Economic Sciences Journal, Issue 45, 2015

[4] Al-Shawarby, A. Credit Risk Management from the Banking and Legal Viewpoints, Al Maarif Establishment, Alexandria, 2002

[5] Al-Mahrouq, M. and Muqabila, I., Small and Medium Enterprises Their Importance and Constraints, Small and Medium Enterprises Center, Amman, Jordan, 2006

[6] Hassan, H. Formulas of Islamic Finance for Small Enterprises. Arab Democratic Center, 2020, posted on 7/4/2020, https://democraticac.de/?p=67613

[7] Ahmed, H. The Role of Islamic Financial Institutions In Financing micro Enterprises: Theory And Evidence", research submitted to the sixth annual symposium, Arab Academy for Science, 2003

[8] Sharrett, K., Zaghlami, M. The Islamic Banking Financing and its Effect on the Malaysian GDP Gross Domestic Product During 2000-2016 - An Analytical and Econometric Study. The Economic Researcher Journal, Vol 6 No. 1, 2016, 112133.

[9] Al-Fawwaz, T., Alawne, M., Shawaqfeh, G. The Impact of Islamic Finance on Some Macro Economic Variables. (A case study of Jordan Islamic Bank, Interdisciplinary Journal of Contemporary Research in Business, Vol. 7, No. 1, 2015

[10] Miqdad, M. and Helles, S. The Role of Islamic Banks in Financing Economic Development in Palestine. Journal of the Islamic University (Humanities Series), Vol. 13 - No. 1, 2005, pp: 239-261
[11] Obada, I., and Melhem, M., The Economic Importance of Islamic Banking Finance in Jordan: Case Study of Jordan Islamic Bank and International Islamic Arab Bank. Journal of Studies, Sharia and Law Sciences. Vol. 46, No. 3, 2019

[12] Al-Barishi, I. Islamic Banks and their Role in Social and Economic Development, Mu'tah Research and Studies Series, Human and Social Sciences Series, Volume 26, No.7, 2011

[13] Union of Arab Banks, 2021 https://uabonline.org/ar

[14] Central Bank of Jordan. Total Credit Facilities granted by Banks to Small and Medium-Sized Enterprises (SMEs). 2020 https://www.cbj.gov.jo/Pages/viewpage.aspx? pageID $=401$

[15] Association of Banks in Jordan: https://www.abj.org.jo/

[16] Daly, S.; Frikha, M.; and McMillan, D. Banks and economic growth in developing countries: What about Islamic banks? Cogent Economics \& Finance. Vol. 4, No. 1, 2016

[17] Yousri, A. "Does Islamic banking help in economic development of Muslim countries?," MPRA Paper 88387, University Library of Munich, Germany, revised 2016

\section{Contribution of individual authors to the creation of a scientific article (ghostwriting policy)}

SALAH TURKI ATEIWI ALRAWAHDEH, and ALI ABDEL FATTAH HAMDA ZYADAT have equally contributed to this scientific study

Creative Commons Attribution License 4.0 (Attribution 4.0 International, CC BY 4.0)

This article is published under the terms of the Creative Commons Attribution License 4.0 https://creativecommons.org/licenses/by/4.0/deed.en US 